\title{
Pre-dehydration treatments and quality of processed potatoes during storage
}

\author{
Dilson Antonio Bisognin ${ }^{1} \mathbb{D}$; Marlene Terezinha Lovatto ${ }^{1} \mathbb{D}$ \\ ${ }^{1}$ Universidade Federal de Santa Maria (UFSM), Santa Maria-RS, Brasil; dilson.bisognin@ufsm.br; mtlovatto@gmail.com
}

\begin{abstract}
The aim of this work was to study pre-dehydration treatments to maintain consumption quality of processed potatoes (Solanum tuberosum) over a long storage period. Tubers of the cultivars Asterix, Macaca and Agata were cut into cubes and submitted to the following pre-dehydration treatments: water (control), blanching, and blanching with different doses of sodium metabisulfite. Sulphur dioxide residue and microorganism detection were determined right after the dehydration process was completed. Water activity, color, rehydration ratio, cooking time and rehydration ratio after cooking were determined at the beginning and after one and two years of storage. Blanching, cultivar and storage affected rehydration ratio, an important parameter used to measure the quality of dehydrated products. Tubers with higher dry mass content resulted in lower water activity and rehydration ratio, longer cooking time and higher rehydration ratio after cooking than those with lower dry mass. The combination of blanching with sodium metabisulfite improves product quality, reduces microbial load, enhances dehydration rate and prevents oxidation and browning reactions during processing and storage. The effects of the structural damages of pre-dehydration and dehydration treatments on the rehydration ratio and the rehydration ratio after cooking increase with storage of processed potatoes.
\end{abstract}

Keywords: Solanum tuberosum, shelf life, rehydration, cooking.

\section{RESUMO}

Tratamentos antes da desidratação e qualidade de batata processada durante $o$ armazenamento

O objetivo deste trabalho foi estudar tratamentos antes da desidratação para manter a qualidade de consumo da batata (Solanum tuberosum) processada durante um longo período de armazenamento. Tubérculos das cultivares Asterix, Macaca e Agata foram cortados em cubos e submetidos aos tratamentos antes da desidratação: água (controle), branqueamento e branqueamento com diferentes doses de metabissulfito de sódio. O resíduo de dióxido de enxofre e a detecção de microrganismos foram determinados logo após a conclusão do processo de desidratação. A atividade de água, a cor, a razão de reidratação, o tempo de cozimento e a razão de reidratação após o cozimento foram determinados no início e após um e dois anos de armazenamento. Branqueamento, cultivar e armazenamento afetaram a razão de reidratação, que é um importante parâmetro da qualidade de produtos desidratados. Tubérculos com maior teor de massa seca resultaram em menor atividade de água e razão de reidratação, maior tempo de cocção e maior taxa de reidratação após o cozimento do que aqueles com menor massa seca. A combinação de branqueamento com metabissulfito de sódio melhora a qualidade do produto, reduz a carga microbiana, aumenta a taxa de desidratação e evita reações de oxidação e escurecimento durante o processamento e armazenamento. Os efeitos dos danos estruturais causados pelos tratamentos antes e durante a desidratação sobre a razão de reidratação e a razão de reidratação após o cozimento aumentam com o tempo de armazenamento da batata processada.

Palavras-chave: Solanum tuberosum, vida de prateleira, rehidratação, cozimento.

\section{Received on January 7, 2021; accepted on October 5, 2021}

$\mathrm{P}$ otato (Solanum tuberosum) is the third most important food, growing in more than 160 countries of five continents (FAO, 2019). It is produced all year round in different growing conditions of Brazil, with approximately $70 \%$ of the total production sold for fresh market (Gitah, 2015). Most potatoes are sold loose that demands good tuber appearance and almost no peel, and some are packed, being $10 \%$ of the cultivar Asterix (frying), and 90\% Agata (cooking) (Gitah, 2015).

Fresh potato tubers have low shelf life, which is an opportunity for the processing industry, including dehydrated products (Gitah, 2015). Dehydration is a process of removing water from foods to reduce water activity and maintain quality of processed foods (Prabhakar \& Mallika, 2014). Dehydration promotes microbiological stability, reduces chemical reactions responsible for deterioration, facilitates storage, and reduces product transportation costs (Sagar \& Kumar, 2010). Besides affecting browning, water activity generally increases microbial growth, since it primarily affects the availability of reaction site and catalytic mobility (Kwok et al., 2010). Reducing water activity inhibits microbial growth and the drying process 
heat reduces microbial load (Sagar \& Kumar, 2010). Convection dehydration is the most common industrial technique for reducing water content, although it damages tissues and rehydration characteristics of foods (Cunningham et al., 2008).

A processing method of dehydrated potato comprises essential steps, as raw material cleaning, peeling, cutting or slicing the tubers, blanching, color protection, drying and packing (Yang, 2018). One concern about dehydrated products is to maintain the quality characteristics (Bevilacqua et al., 2017), in this case the original flavor of potato (Yang, 2018). The stabilization of the microbial activity is also necessary for a long-term storage of dehydrated foods (Bevilacqua et al., 2017). Among pre-dehydration treatments, hot water blanching is the most popular and commercially used to reduce microbial load, enhance dehydration rate and product quality, inactivate enzymes, eliminate air from intercellular spaces, and minimize nonenzymatic browning (Luo et al., 2011; Xiao et al., 2015). Sulfitation agents prevent oxidation, bacterial growth and control enzymatic browning reactions during production and non-enzymatic reactions during storage, being sodium metabisulfite the most extensively used as food preservative (Lindsay, 2008). Pre-treatments with combined methods applied before dehydration, such as blanching and sulfitation, are practical and efficient ways to control oxidation, which causes browning during the preparation and storage of dehydrated foods (Ioannou \& Ghoul, 2013; Shakouri et al., 2015). Blanching is a heat treatment in steam, hot water or microwave before dehydration.

Dehydrated potatoes can be ground and used to produce flour with various uses, including soup formulations and nutritional enrichment of dehydrated soups (Los et al., 2018). Dehydrated products are generally hydrated before consumption to restore their properties, allowing rehydrated products to present similar characteristics to those of the fresh product. In some cases, rehydration can be considered a measure for the tissue damage caused during the process of dehydration (Vega-Gálvez et al., 2009).

Considering that pre-dehydration treatments might affect quality and conservation of dehydrated potato cubes, the aim of this work was to study pre-dehydration treatments to maintain consumption quality of processed potatoes over a long storage period.

\section{MATERIAL AND METHODS}

The experiments were carried out at the Fruit and Vegetable Processing Laboratory of the Polytechnic College, and at the Center of Plant Breeding and Vegetative Propagation, both of the Federal University of Santa Maria. Potato tubers of the cultivars Asterix, Macaca and Agata were used with the lowest diameter greater than $45 \mathrm{~mm}$ and without apparent external defects. The dry mass content of each cultivar was quantified by drying the tubers in a forced air circulation oven at $60^{\circ} \mathrm{C}$ until constant weight. To ensure quality of the final product, sanitation of the process was guaranteed by using procedures established by good manufacturing practices. Utensils, equipment and tubers were sanitized with a sodium hypochlorite solution, containing 200 $\mathrm{mg} \mathrm{L}^{-1}$ of free chlorox and $\mathrm{pH}$ adjusted to 7.0 .

The sanitized tubers were peeled mechanically by abrasion and prepared by removing remaining peel, gashes and deep buds and other external defects. Then, the tubers were sanitized in a solution of sodium dichloro-striazinetrione, with $100 \mathrm{mg} \mathrm{L}^{-1}$ of free chlorox and $\mathrm{pH}$ adjusted to 7.0 at a temperature of $15^{\circ} \mathrm{C}$ for $15 \mathrm{~min}$. Then, they were sectioned into slices of approximately $1 \mathrm{~cm}$ in thickness and cut into cubes $\left(1 \mathrm{~cm}^{3}\right)$, using a mechanical vegetable cutter (Delta). The cubes were centrifuged at $460 \mathrm{rpm}$ for $4 \mathrm{~min}$ to remove water excess before treatment.

The pre-dehydration treatments were defined in preliminary tests. Based upon the literature, we evaluate sodium metabisulfite, ascorbic acid, citric acid and sodium chloride in different exposure times and concentrations. Blanching was evaluated with water and with different concentrations of sodium chloride or sucrose. Combination of blanching and different concentration of sodium metabisulfite were also tested before defining the final treatments. Cubes of the potato cultivars Asterix, Macaca and Agata were treated with water (control), blanching, blanching and sodium metabisulfite $\left(\mathrm{Na}_{2} \mathrm{~S}_{2} \mathrm{O}_{5}\right)$ $0.05 \%$, blanching and sodium metabisulfite $0.1 \%$, and blanching and sodium metabisulfite $0.2 \%$. For blanching treatment, $1 \mathrm{~kg}$ of potato cubes was immersed in $3 \mathrm{~L}$ of a $2 \%$ sodium chloride solution at $80^{\circ} \mathrm{C}$ for 6 min. For other pre-dehydration treatments, $1 \mathrm{~kg}$ of potato cubes was immersed in $2 \mathrm{~L}$ water (control) or in the respective sodium metabisulfite solution at $15^{\circ} \mathrm{C}$ for $10 \mathrm{~min}$. After treated, potato cubes were centrifuged at $460 \mathrm{rpm}$ for 4 min before dehydration.

For dehydration, potato cubes were distributed onto eight trays, $1.5 \mathrm{~kg}$ per tray and homogenized to form a single layer. When all trays were complete, they were placed in a forced air dehydrator (model PEG 30 Classic, Pardal), previously heated to $60^{\circ} \mathrm{C}$ and kept at this temperature throughout the process of dehydration. Mass loss was verified every hour by weighing the trays using a digital scale with $5 \mathrm{~g}$ precision. The process was terminated when mass variation between two intervals was equal to or below $10 \%$ of the initial mass (defined in preliminary tests). After dehydration, the product remained in the trays with the compartment closed until reaching room temperature. The cubes were conditioned in glass containers, hermetically sealed and identified. Dehydrated cubes of the three potato cultivars were stored at room temperature, with an average temperature of $20^{\circ} \mathrm{C}$.

Residual $\mathrm{SO}_{2}$ determination and microorganism detection were carried out before storing the dehydrated cubes. Residual $\mathrm{SO}_{2}$ was determined by the method described in the Association of Official Analytical Chemists International (AOAC, 2005). Microorganism detection was performed according to the method described in the IN $n^{\circ} 62$, by counting total and thermotolerant coliforms, expressed 
as UFC $\mathrm{g}^{-1}$, and for Salmonella sp., as the presence or absence in $25 \mathrm{~g}$ of sample (Brasil, 2003). Evaluations of water activity, rehydration ratio, cooking time, rehydration ratio after cooking, and color were carried out at the beginning and after one and two years of storage at room temperature. Water activity of the samples was determined using a Testo 650 Meter, model 05636501. Color was determined in a colorimeter (Minolta CR-300) and expressed as coordinates $L^{*}, a^{*}$ and $b^{*}$ in three readings for each sample. Rehydration ratio was calculated for the water and blanching itself. A total of $50 \mathrm{~g}$ of sample was added to 500 $\mathrm{mL}$ water at room temperature $\left(20^{\circ} \mathrm{C}\right)$ for $30 \mathrm{~min}$, as defined in preliminary test. Water was drained, potato sample weighted and data used to calculate the rehydration ratio, which is equal to the rehydrated mass divided by dehydrated mass. The rehydrated samples were placed in recipients containing $1 \mathrm{~L}$ water at $90^{\circ} \mathrm{C}$, where they were kept until cooked. Cooking time was defined as no chalky aspect in the internal part of sectioned cubes. The cooking time was recorded, the cooking water drained and the mass of the samples determined. The rehydration ratio after cooking was determined as cooked rehydrated mass divided by dehydrated mass.

Data were submitted to variance analysis as a factorial model ( 3 cultivars x 5 pre-dehydration treatments $\times 3$ storage times) in the random design, with eight repetitions. For significant F-test, treatment means were compared by Duncan test at $5 \%$ probability of error. The analyses were run with the SAEG software program.

\section{RESULTS AND DISCUSSION}

The highest residual $\mathrm{SO}_{2}$ content (152 $\left.\mathrm{mg} \mathrm{kg}^{-1}\right)$ was found in dehydrated potato cubes treated with sodium metabisulfite and no trace was found in the cubes of the control (water) treatment (Table 1). As legislation for intentional additives allows a maximum value of $200 \mathrm{mg} \mathrm{kg}^{-1}$ of residual $\mathrm{SO}_{2}$ in dehydrated vegetables (Brasil, 1988), even the potato cubes treated with the highest concentration of sodium metabisulfite and dehydrated presented a residual $\mathrm{SO}_{2}$ content within the legal limit. The pre-dehydration treatments applied to maintain quality also contributed to ensure microbiological control in the potato cubes dehydrated at $60^{\circ} \mathrm{C}$, as both the most probable number of thermotolerant coliforms $\left(45^{\circ} \mathrm{C}\right)$ and of total coliforms $\left(35^{\circ} \mathrm{C}\right)$ per gram of sample were within parameters allowed by the Brazilian legislation (Brasil, 2003). The same was found for Salmonella sp., which was absent in the samples analyzed (data not shown). Therefore, sanitation before and after peeling the tubers was efficient to reduce microbial load, since tubers are in contact with contaminant microorganisms during production, harvest and postharvest management. Blanching was also efficient to reduce microbial load, since this pre-dehydration treatment resulted in total and thermotolerant coliforms and Salmonella sp. most probable number below three, which was an expecting effect of blanching treatment (Xiao et al., 2015).

Analysis of variance showed that water activity and color were not affected by storing dehydrated potato cubes for two years (Table 2). In addition, cultivar and pre-dehydration treatments showed independent effect, since the interaction was not significant. Potato cultivar and pre-dehydration treatments affected water activity and color of processed product. The control pre-dehydration treatment and the cultivars Asterix and Macaca resulted in the lowest water activity. Blanching predehydration treatment resulted in higher water activity, because the gelatinization of starch seems to influence softening and water retention capacity in parenchymatous tissue (Bemiller \& Huber, 2008). Besides preventing enzymatic browning, blanching improves proteins and soluble fibers in dehydrated potato flour (Nascimento \& Canteri, 2018). The dehydration process was efficient to reduce water activity independent of the pre-dehydration and cultivar, resulting in potato cubes with water activity between 0.62 and 0.69 that inhibit microorganism growth and leads to a long shelf life of the processed product (Bevilacqua et al., 2017).

Dehydrated potatoes can be stored in hermetically sealed glass containers, since there was no change in water activity during the period of two years at room temperature (Table 2). Considering the coordinates values for brightness, redness, and yellowness, blanching associated with different

Table 1. Residual $\mathrm{SO}_{2}$ content and most probable number of thermotolerant coliforms $\left(45^{\circ} \mathrm{C}\right)$ and total coliforms $\left(35^{\circ} \mathrm{C}\right)$ per gram of potato cubes of cultivars Asterix, Macaca and Agata after dehydration at $60^{\circ} \mathrm{C}$. Santa Maria, UFSM, 2013.

\begin{tabular}{|c|c|c|c|c|c|c|c|c|c|}
\hline \multirow{2}{*}{ Treatments* $^{*}$} & Asterix & Macaca & Agata & \multicolumn{2}{|c|}{ Asterix } & \multicolumn{2}{|c|}{ Macaca } & \multicolumn{2}{|c|}{ Agata } \\
\hline & \multicolumn{3}{|c|}{ Residual $\mathrm{SO}_{2}\left(\mathrm{mg} \mathrm{kg}^{-1}\right)$} & $45^{\circ} \mathrm{C}$ & $35^{\circ} \mathrm{C}$ & $45^{\circ} \mathrm{C}$ & $35^{\circ} \mathrm{C}$ & $45^{\circ} \mathrm{C}$ & $35^{\circ} \mathrm{C}$ \\
\hline & & & & \multicolumn{6}{|c|}{ Most probable number ${ }^{2}$} \\
\hline Water (control) & $\mathrm{ND}<10$ & $\mathrm{ND}<10$ & $\mathrm{ND}<10$ & $4.6 \times 10^{1}$ & $2.4 \times 10^{3}$ & $7 \times 10^{1}$ & $2.8 \times 10^{3}$ & $3.4 \times 10^{1}$ & $3.5 \times 10^{3}$ \\
\hline Blch & $\mathrm{ND}<10$ & $\mathrm{ND}<10$ & $\mathrm{ND}<10$ & $<3.0$ & $<3.0$ & $<3.0$ & $<3.0$ & $<3.0$ & $<3.0$ \\
\hline Blch + SM $0.05 \%$ & 8.43 & 19.87 & 58.77 & $<3.0$ & $<3.0$ & $<3.0$ & $<3.0$ & $<3.0$ & $<3.0$ \\
\hline Blch + SM $0.1 \%$ & 32.56 & 55.19 & 63.33 & $<3.0$ & $<3.0$ & $<3.0$ & $<3.0$ & $<3.0$ & $<3.0$ \\
\hline Blch + SM $0.2 \%$ & 83.12 & 115.91 & 151.86 & $<3.0$ & $<3.0$ & $<3.0$ & $<3.0$ & $<3.0$ & $<3.0$ \\
\hline
\end{tabular}

${ }^{*}$ For blanching (Blch), $1 \mathrm{~kg}$ of potato cubes was immersed in $3 \mathrm{~L}$ of a $\%$ sodium chloride solution at $80^{\circ} \mathrm{C}$ for 6 min. For other treatments, $1 \mathrm{~kg}$ of potato cubes was immersed in $2 \mathrm{~L}$ water (control) or in the respective sodium metabisulfite (SM) solution at $15^{\circ} \mathrm{C}$ for $10 \mathrm{~min}$. $\mathrm{ND}=$ not detected. 
concentrations $(0.05,0.1$ and $0.2 \%)$ of sodium metabisulfite were efficient to control enzymatic and non-enzymatic browning and caramelization. Therefore, sodium metabisulfite was effective to prevent browning, both during processing and storage of dehydrated potato cubes for a long period (two years of storage), which agrees with

the fact of being the most effective and frequently used as antibrowning agent (Oliphant et al., 2012). Potato cultivars and pre-dehydration treatments influenced redness. The blanching treatment presented the highest value, differing from the water treatment, while the blanching associated with sodium metabisulfite treatments did

Table 2. Water activity and color coordinates for brightness $\left(L^{*}\right)$, redness $\left(a^{*}\right)$, and yellowness $\left(b^{*}\right)$ in potato cubes of cultivars Asterix, Macaca and Agata submitted to pre-dehydration treatments, dehydrated at $60^{\circ} \mathrm{C}$ and stored at room temperature during two years. Santa Maria, UFSM, 2013.

\begin{tabular}{|c|c|c|c|c|c|c|c|}
\hline \multirow{2}{*}{ Treatments $^{1}$} & \multirow{2}{*}{$\begin{array}{c}\text { Water } \\
\text { activity }\end{array}$} & \multicolumn{6}{|c|}{ Color coordinates } \\
\hline & & $L^{*}$ & & $a^{*}$ & & $b^{*}$ & \\
\hline Water (control) & $0.602 \mathrm{c}^{2}$ & 52.47 & $\mathrm{~b}$ & 3.65 & $\mathrm{~b}$ & 16.28 & $\mathrm{c}$ \\
\hline Blch & $0.678 \mathrm{ab}$ & 49.41 & $\mathrm{c}$ & 5.95 & $\mathrm{a}$ & 28.05 & $\mathrm{~b}$ \\
\hline Blch + SM 0.05\% & $0.649 \mathrm{~b}$ & 58.57 & $\mathrm{a}$ & 2.35 & $\mathrm{c}$ & 40.27 & $\mathrm{a}$ \\
\hline Blch + SM 0.1\% & $0.690 \quad \mathrm{a}$ & 59.14 & $\mathrm{a}$ & 2.19 & $\mathrm{c}$ & 42.10 & $\mathrm{a}$ \\
\hline Blch + SM 0.2\% & $0.663 \mathrm{ab}$ & 60.22 & $\mathrm{a}$ & 1.57 & $\mathrm{c}$ & 42.49 & $\mathrm{a}$ \\
\hline \multicolumn{8}{|l|}{ Cultivars } \\
\hline Asterix & $0.653 \mathrm{~b}$ & 54.51 & $\mathrm{~b}$ & 3.97 & $\mathrm{a}$ & 34.57 & 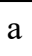 \\
\hline Macaca & $0.641 \quad b$ & 57.20 & $\mathrm{a}$ & 2.38 & $\mathrm{c}$ & 31.42 & $\mathrm{~b}$ \\
\hline Agata & 0.676 a & 56.35 & $\mathrm{a}$ & 3.07 & $\mathrm{~b}$ & 35.21 & $\mathrm{a}$ \\
\hline
\end{tabular}

${ }^{1}$ For blanching (Blch), $1 \mathrm{~kg}$ of potato cubes was immersed in $3 \mathrm{~L}$ of a $2 \%$ sodium chloride solution at $80^{\circ} \mathrm{C}$ for $6 \mathrm{~min}$. For other treatments, $1 \mathrm{~kg}$ of potato cubes was immersed in $2 \mathrm{~L}$ water (control) or in the respective sodium metabisulfite $(\mathrm{SM})$ solution at $15^{\circ} \mathrm{C}$ for $10 \mathrm{~min}$. ${ }^{2}$ Treatments followed by the same letter did not differ by the Duncan test at $p \leq 0.05$.

Table 3. Rehydration ratio, cooking time and rehydration ratio after cooking of potato cubes of the cultivars Asterix, Macaca and Agata submitted or not to blanching, dehydrated at $60^{\circ} \mathrm{C}$, stored at room temperature during two years and rehydrated at $20^{\circ} \mathrm{C}$ for $30 \mathrm{~min}$. Santa Maria, UFSM, 2013.

\begin{tabular}{|c|c|c|c|}
\hline Treatments & $\begin{array}{c}\text { Rehydration } \\
\text { ratio }^{2}\end{array}$ & $\begin{array}{l}\text { Cooking time } \\
(\text { min) }\end{array}$ & $\begin{array}{l}\text { Rehydration ratio } \\
\text { after cooking }\end{array}$ \\
\hline \multicolumn{4}{|l|}{ Blanching $^{1}$} \\
\hline With & $1.23 \mathrm{a}^{4}$ & $10.51 \mathrm{~b}$ & $2.58 \mathrm{a}$ \\
\hline Without & $1.10 \mathrm{~b}$ & $12.29 \mathrm{a}$ & $2.48 \mathrm{~b}$ \\
\hline \multicolumn{4}{|l|}{ Cultivars } \\
\hline Asterix & $1.12 \mathrm{~b}$ & $12.91 \mathrm{a}$ & $2.41 \mathrm{c}$ \\
\hline Macaca & $1.16 \mathrm{ab}$ & $10.52 \mathrm{~b}$ & $2.51 \mathrm{~b}$ \\
\hline Agata & $1.22 \mathrm{a}$ & $10.77 \mathrm{~b}$ & $2.68 \mathrm{a}$ \\
\hline \multicolumn{4}{|l|}{ Storage (years) } \\
\hline Beginning (0) & $1.32 \mathrm{a}$ & $10.99 \mathrm{~b}$ & $2.75 \mathrm{a}$ \\
\hline After 1 year (1) & $1.10 \mathrm{~b}$ & $13.54 \mathrm{a}$ & $2.53 \mathrm{~b}$ \\
\hline After 2 years (2) & $1.08 \mathrm{~b}$ & $9.66 \mathrm{~b}$ & $2.31 \mathrm{c}$ \\
\hline
\end{tabular}

${ }^{1}$ Blanching in water heated to $80^{\circ} \mathrm{C}$ (proportion of $1 \mathrm{~kg}$ sample to $3 \mathrm{~L}$ water) for $6 \mathrm{~min}$. ${ }^{2}$ Rehydration with water at $20^{\circ} \mathrm{C}$ for $30 \mathrm{~min}$, measured by the rehydration ratio $=$ rehydrated mass / dehydrated mass. ${ }^{3}$ Rehydration ratio after cooking = cooked rehydrated mass / dehydrated mass. ${ }^{4}$ Treatments followed by the same letter did not differ by the Duncan test at $p \leq 0.05$. not differ among each other, but did differ from the other ones. Therefore, sodium metabisulfite presented the lowest mean value for redness, favoring the yellow chrome that is desirable for dehydrated potatoes, meaning that sodium metabisulfite is necessary for the characteristic color maintenance of dehydrated potato products.

Texture and color are the most important quality parameters in processed products derived from potato. Color is considered the most important visual attribute in the perception of the product quality, since it is often the basis for consumer's selection or rejection (Carmo \& Lima, 2005). The color evaluation in the dehydrated cubes revealed differences among cultivars and pre-dehydration treatments (Table 2 and Figure 1). Blanching combined with different concentrations of sodium metabisulfite did not differ among each other, but they differed from water and blanching treatments (Table 2) as well as verified for cultivars Asterix, Macaca and Agata (Figure 1). Adding sodium metabisulfite increased brightness and yellowness and reduced redness. Pretreating cylindrical potato samples also increase yellowness and decrease redness (Dhalsamant et al., 2017). Therefore, sodium metabisulfite, even in the concentration of $0.05 \%$, was very important to prevent oxidation and control enzymatic browning reactions during production and non-enzymatic reactions during storage of dehydrated potatoes. The optimized quality of potato cubes was found with the combination of blanching with dipping in a sodium metabisulfite solution of $0.04 \%$ (Varnalis et al., 2004).

The evaluated cultivars of potato, the blanching pre-dehydration treatment and the time of storage in hermetically sealed glass containers at room temperature affected rehydration ratio, cooking time and rehydration ratio after cooking (Table 3 ). The rehydration ratio, an important parameter used to measure the quality of dried foods (Doymaz \& Ismail, 2011), of the cultivar Agata was higher than that of Asterix, which was not different from Macaca. It is accepted that tissues with higher dry mass content have their cellular structure altered by 


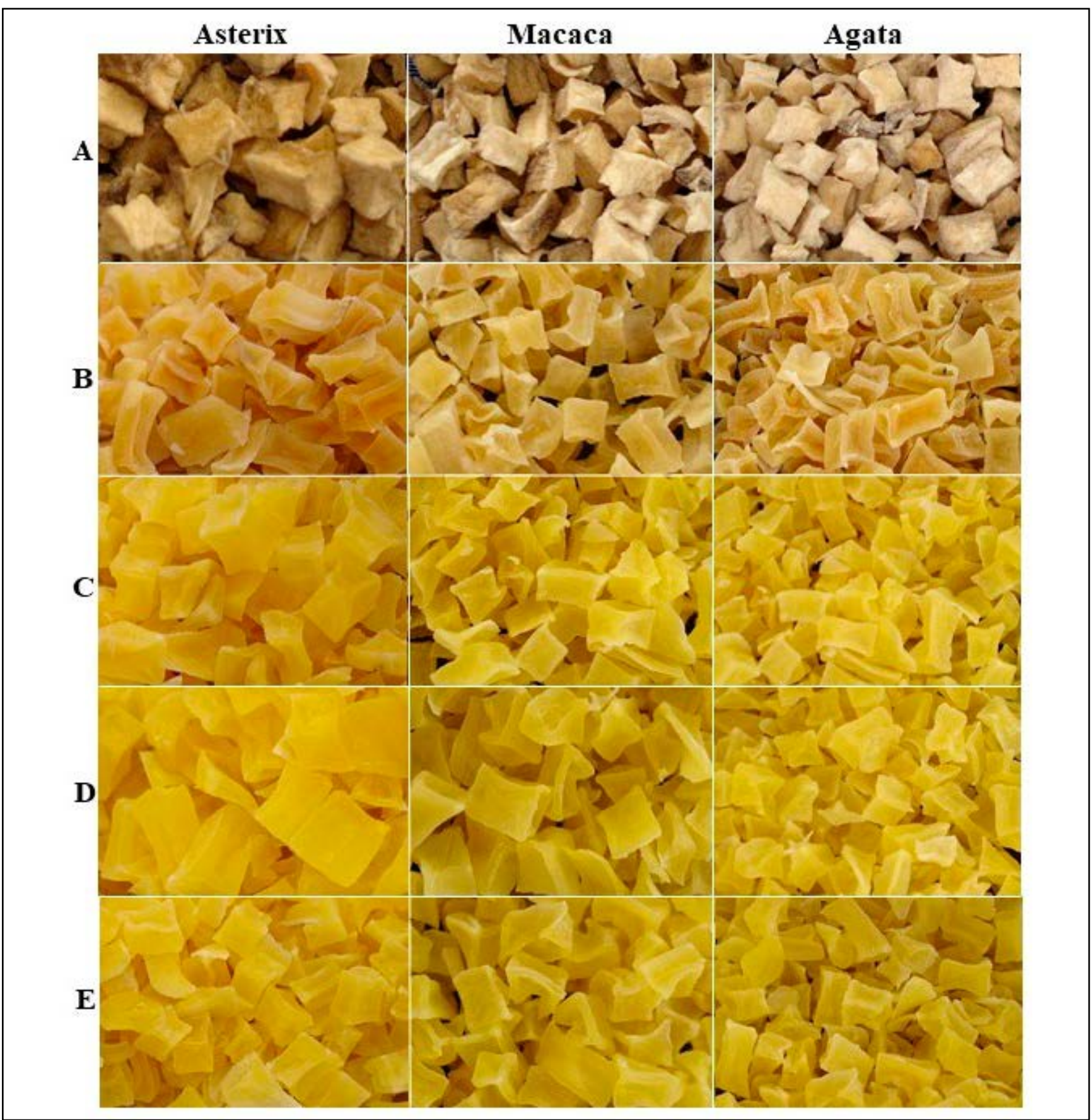

Figure 1. Color of potato cubes of the cultivars Asterix, Macaca and Agata submitted to pre-dehydration treatments $(\mathrm{A}=\mathrm{control} ; \mathrm{B}=$ blanching, $\mathrm{C}=$ blanching and sodium metabisulfite $0.05 \% ; \mathrm{D}=$ blanching and sodium metabisulfite $0.1 \%$; and $\mathrm{E}=$ blanching and sodium metabisulfite $(0.2 \%)$ and dehydrated at $60^{\circ} \mathrm{C}$. Santa Maria, UFSM, 2013.

the expansion caused by gelatinization of starch (Bemiller \& Huber, 2008) and, consequently, absorbed a lower amount of water. As Agata had the lowest content of dry mass $(18 \%)$, compared to Asterix (22\%) and Macaca (21\%), the difference in dry mass content was sufficient to affect rehydration ratio. The cultivar Asterix cooked for the longest time, while Macaca and Agata did not differ from each other. Potato cultivar also influenced rehydration ratio and rehydration ratio after cooking. The cultivar Agata presented the highest rehydration ratio after cooking, followed by Macaca and then Asterix, showing that the rehydration ratio after cooking was directly related to the dry mass content of the evaluated cultivars. Therefore, the dry mass content, a genetically inherited and an important trait of potato cultivars, affected rehydration ratio, cooking time and rehydration ratio after cooking.

The hydrothermal degradation of pectin in the middle lamella, in the primary cell walls and between lamellas and cell walls should be a weakening factor in the parenchymatous structure of potato cells (Liu \& Scanlon, 2007). The 
greater the content of starch granules in the tissues, the greater the pressure of swelling caused by blanching, since the starch grains begin to gelatinize between 58 and $65^{\circ} \mathrm{C}$ (Bemiller \& Huber, 2008). The rehydration ratio at the beginning was higher than that found after one and two years of storage, which did not differ among one another. This means that as time goes by, the internal collapse of tissues increases. After one year of storage, the time needed to cook the potato cubes was greater than that at the beginning and at the end of the second year of storage, which did not differ among one another. Right after dehydration, potato cubes had the highest rehydration ratio after cooking, followed by one and two years of storage. This result is related to the rehydration ratio, which depends on the degree of structural rupture that occurs during pre-dehydration and dehydration treatments (Bilbao-Sáinz et al., 2005), since the damage manifests itself throughout the storage period.

In this study, we identify and select practical procedures to produce dehydrated potatoes with high consumption quality during a long storage period at room temperature. Dehydration is a well-known technology to promote microbiological stability, reduce chemical deterioration, facilitate storage and reduce transportation costs. Therefore, dehydration is a very important technology for improving shelf life and increasing supply and uses of fresh tubers of potato. The major goal is to reduce water content, usually by convection dehydration, which reduces water activity necessary for microbial growth and chemical reactions. The use of postharvest handling procedures, associated with pre-dehydration treatments and convention dehydration resulted in a dehydrated product with low microbial load and water activity, and long storage period, even at room temperature. Therefore, dehydration is a feasible technology and an opportunity for the processing industry to develop innovative products with high consumption quality during a long storage period, expanding supply and uses of potato, the third most important food worldwide, produced during the whole year in Brazil and usually sold as fresh tubers.

\section{REFERENCES}

AOAC. 2005. Official methods of analysis of the $A O A C .18^{\text {th }}$ ed. Gaithersburg: AOAC International.

BEMILLER, JN; HUBER, KC. 2008. Carbohydrates. In: DAMADARAN, S; PARKIN, KL; FENNEMA, OR (eds). Fennema's Food Chemistry. 4ed. Boca Raton: CRC Press, p.83-154. 1144p.

BEVILACQUA, A; CORBO, MR; SINIGAGLIA, M. 2017. The microbial quality of food Foodborn spoilers. United Kingdom: Elsevier, 310p.

BILBAO-SÁINZ, C; ANDRÉS, A; FITO, P. 2005. Hydration kinetics of dried apple as affected by drying conditions. Journal of Food Engineering 68: 369-376.

BRASIL. 1988. Aditivos Intencionais. Resolução $\mathrm{n}^{\circ} 04$ de 24 de novembro de 1988.

BRASIL. 2003. Métodos analíticos oficiais para análises microbiológicas para controle de produtos de origem animal e água. Instrução normativa $\mathrm{n}^{\circ} 62$ de 26 de agosto de 2006.

CARMO, JEF; LIMA, AGB. 2005. Drying of lentils including shrinkage: a numerical simulation. Dry Technology 23: 1977-1992.

CUNNINGHAM, SE; MCMINN, WAM; MAGEE, TRA; RICHARDSON, PS. 2008. Experimental study of rehydratation kinetics of potato cylinders. Food and Bioproducts Processing 86: 15-24.

DHALSAMANT, K; TRIPATHY, PP; SHRIVASTAVA, SL. 2017. Effect of pretreatment on rehydration, colour and nanoindentation properties of potato cylinders dried using a mixed-mode solar dryer. Journal of the Science of Food and Agriculture 97: 3312-3322.

DOYMAZ, I; ISMAIL, O. 2011. Drying characteristics of sweet cherry. Food and Bioproducts Processing 89: 31-38.

FAO. 2019. Food and Agriculture Organization of the United Nations: FAOSTAT/Crops/Potatoes. Available from: http://www.fao.org/faostat/ en/\#data/QC.

GITAH. 2015. Opportunities in the potato sector Brazil. Available from: http://www.agriment. com/files/opportunities_potato_sector_brazil. pdf.

IOANNOU, I; GHOUL, M. 2013. Prevention of enzymatic browning in fruit and vegetables. European Scientific Journal 9: 310-341.

KWOK, K; MAUER, LJ; TAYLOR, LS. 2010. Kinetics of moisture-induced hydrolysis in powder blends stored at and below the deliquescence relative humidity: investigation of sucrose-citric acid mixtures. Journal of Agriculture and Food Chemistry 58: 1171611724.

LINDSAY, RC. 2008. Food additives. In: DAMADARAN, S; PARKIN, KL; FENNEMA, OR (eds). Fennema's food chemistry. 4ed. Boca Raton: CRC Press, p.689-749. 1144p.

LIU, EZ; SCANLON, MG. 2007. Modeling the effect of blanching conditions on the texture of potato strips. Journal of Food Engineering 81: 292-297.

LOS, PR; SIMÕES, DRS; LEONE, RS; BOLANHO, BC; CARDOSO, T; DANESI, ED. 2018. Viability of peach palm byproduct, Spirulina platensis, and spinach for the enrichment of dehydrated soup. Pesquisa Agropecuária Brasileira 53: 1259-1267.

LUO, Y; LU, S; ZHOU, B; FENG, H. 2011. Dual effectiveness of sodium chlorite for enzymatic browning inhibition and microbial inactivation on fresh-cut apples. LWT-Food Science and Technology 44: 1621-1625.

NASCIMENTO, RF; CANTERI, MHG. 2018. Effect of blanching on physicochemical characteristics of potato flour. Horticultura Brasileira 36: 461-465.

OLIPHANT, T; MITRA, A; WILKINSON, M. 2012. Contact allergy to sodium sulfite and its relationship to sodium metabisulfite. Contact Dermatitis 66: 128-130.

PRABHAKAR, K; MALLIKA, EN. 2014. Dried foods. In: ROBINSON, R (ed). Encyclopedia of food microbiology. Oxford: Elsevier, $2^{\text {nd }}$ Edition: 574-576, $3248 \mathrm{p}$.

SAGAR, VR; KUMAR, S. 2010. Recent advances in drying and dehydration of fruits and vegetables: A review. Journal of Food Science and Technology 47: 15-26.

SHAKOURI, S; ZIAOLHAGH, HR; SHARIFIRAD, J; HEYDARI-MAJD, M; TAJALI, R; NEZARAT, S; SILVA, JAT. 2015. The effect of packaging material and storage period on microwave-dried potato (Solanum tuberosum L.) cubes. Journal of Food Science and Technology 52: 3899-3910.

VARNALIS, AI; BRENNAN, JG ; MACDOUGALL, DB; GILMOUR, SG. 2004. Optimization of high temperature puffing of potato cubes using response surface methodology. Journal of Food Engineering 61: 153-163

VEGA-GÁLVEZ, A; NOTTE-CUELLO, E; LEMUS-MONDOCA, R; ZURA, L; MIRANDA, M. 2009. Mathematical modelling of mass transfer during rehydration process of Aloe vera (Aloe barbadensis Miller). Food and Bioproducts Processing 87: 254-260.

XIAO, HW; PAN, Z; DENG, LZ; EL-MASHAD, HM; YANG, WH; MUJUMDAR, AS; GAO, ZJ; ZHANG, Q. 2015. Recent developments and trends in thermal blanching - a comprehensive review. Information Processing in Agriculture 4: 101-127.

YANG, R. 2018. CN108936465A - Processing method of dehydrated potato grains. 